\title{
Acoustic evaluation of loblolly pine tree- and lumber-length logs allows for segregation of lumber modulus of elasticity, not for modulus of rupture
}

\author{
Mark Alexander Butler ${ }^{1} \cdot$ Joseph Dahlen $^{1} \cdot$ Thomas L. Eberhardt $^{2} \cdot$ Cristian Montes $^{1}$ • \\ Finto Antony ${ }^{1} \cdot$ Richard F. Daniels $^{1}$
}

Received: 29 March 2016 / Accepted: 28 December 2016 /Published online: 15 February 2017

(C) INRA and Springer-Verlag France 2017

\begin{abstract}
- Key message Loblolly pine (Pinus taeda) logs can be evaluated using acoustic velocity whereby threshold acoustic velocity values can be set to ensure lumber meets specified mechanical property design values for modulus of elasticity.
\end{abstract}

Acoustic evaluation loblolly pine logs and lumber

Handling Editor: Jean-Michel Leban

Contribution of the co-authors Mark Alexander Butler: experimental design, fieldwork and data analysis; Joseph Dahlen: research project coordinator, experimental design, fieldwork, data analysis and writing the paper; Thomas L. Eberhardt: writing the paper; Cristian Montes: data analysis and writing the paper; Finto Antony: experimental design, fieldwork and writing the paper; Richard F Daniels: experimental design and fieldwork.

Joseph Dahlen

jdahlen@uga.edu

Mark Alexander Butler

mabutler@ustrust.com

Thomas L. Eberhardt

teberhardt@fs.fed.us

Cristian Montes

crmontes@uga.edu

Finto Antony

fintoa@gmail.com

Richard F. Daniels

ddaniels@uga.edu

1 Warnell School of Forestry and Natural Resource, University of Georgia, 180 E Green Street, Athens, GA 30602-2152, USA

2 Forest Products Laboratory, USDA Forest Service, One Gifford Pinchot Drive, Madison, WI 53726, USA
- Context There is a need to better sort logs according to lumber quality for improved decision making and wood utilization because merchantable logs are being harvested from different stand types including natural forests, conventional plantations, and intensively managed plantations, all with differences in rotation ages, growth rates, and wood quality traits. - Aims This study aimed to link tree- and lumber-length log acoustic velocity with the resulting lumber properties as tested in static bending from five intensively managed loblolly pine stands in the Atlantic Coastal Plain of Georgia.

- Methods Acoustic velocity was measured using the resonance-based approach on 87 tree-length logs and 244 lumber-length logs. The logs were then processed into 797 pieces of $38 \mathrm{~mm}$ by $89 \mathrm{~mm}(2 \times 4), 140 \mathrm{~mm}(2 \times 6), 184 \mathrm{~mm}$ $(2 \times 8)$, and $235 \mathrm{~mm}(2 \times 10)$ dimension lumber, dried, and tested in static bending.

- Results Mean MOE of the lumber had moderate relationships with acoustic velocity of the $\operatorname{logs}\left(R^{2}=0.49\right)$ whereas MOR and acoustic velocity did not have a strong relationship $\left(R^{2}=0.20\right)$. Accounting for log position increased the performance of the mean lumber MOE model $\left(R^{2}=0.62\right)$ which was further increased by adding green density and small-end diameter $\left(R^{2}=0.67\right)$. Utilization of acoustics was effective for segregating logs based on lumber modulus of elasticity and did not depend on knowing tree or stand information such as age, site quality, and silviculture history.

- Conclusion Acoustic velocity evaluation of tree- and lumber-length logs could be employed to segregate logs within the supply chain to ensure that lumber would meet specified design values.

Keywords Design values · Intensively managed plantations · Mechanical properties $\cdot$ Modulus of elasticity $\cdot$ Modulus of rupture $\cdot$ Nondestructive technology $\cdot$ Southern pine $\cdot$ Wood quality 


\section{Introduction}

Loblolly pine (Pinus taeda), the most important southern pine (P. taeda, Pinus palustris, Pinus echinata, and Pinus elliottii) in terms of utilization, is widely planted as a forest crop in the Southeastern United States and has been extensively improved through genetic selection (McKeand et al. 2003). One of the most important products produced from loblolly pine is dimension lumber. The National Design Specifications (NDS), or design values, for visually graded southern pine were revised in 2013 following testing conducted by the Southern Pine Inspection Bureau (SPIB) (SPIB 2013). Bending strength $\left(\mathrm{F}_{\mathrm{b}}\right)$ design values decreased for all grades and sizes, the modulus of elasticity (MOE) design value for the Select Structural grade was left unchanged at $12.4 \mathrm{GPa}$, but the No. 1 grade MOE decreased from 11.7 to $11.0 \mathrm{GPa}$, and the No. 2 grade MOE decreased from 11.0 to $9.7 \mathrm{GPa}$ (SPIB 2013). The prior design values for southern pine date back to testing on full-sized lumber in the 1980s (Green et al. 1989). The 1980 tests were the first time that design values in North America were based on actual lumber testing and not testing of small clear specimens with resultant data scaled up to lumber sizes (Green et al. 1989).

Over the past 30 years, the acceleration of the growth rate in plantations has increased both the sustainability of forest plantations in the South and their financial attractiveness (Munsell and Fox 2010). Plantation growth has accelerated because of improved genetics, intensive site preparations, weed control, decreased planting densities, and the use of multiple fertilizer applications (Borders and Bailey 2001). These treatments have combined to decrease the time it takes to grow loblolly pine sawtimber from 35-40 down to 20-25 years (Clark et al. 2008) with merchantable size for the chip-n-saw being reached in as little as 16 years (Clark et al. 2008; Vance et al. 2010). The benefits of accelerated growth are often offset by changes to the quality of the wood of standing timber. Specifically, faster grown trees will typically contain a high proportion of juvenile wood which has low stiffness and strength (USDA 1988; McAlister and Clark 1991; Larson et al. 2001).

Nondestructive evaluation (NDE) via acoustics has proven useful for measuring different physical and mechanical properties of materials and to sort logs with varying MOE (Carter et al. 2006; Ross 2015). The relationship between dynamic MOE and acoustic velocity is as follows:

$\mathrm{MOE}_{\mathrm{dyn}}=p V^{2}$

where $\mathrm{MOE}_{\mathrm{dyn}}$ is the dynamic MOE, $p$ is the density, and $V$ is the acoustic velocity. Distinctly different approaches are used for standing trees and logs. To evaluate the acoustic velocity of standing trees, transducers are positioned along the bole, at a known distance in between, and time-of-flight information recorded (Grabianowski et al. 2006; Wessels et al. 2011). Logs are instead evaluated by a resonance-based approach that measures the frequency of numerous acoustic pulses from the larger end of the $\log$, and giving a weighted mean acoustic velocity value $\left(V_{R}\right)$ via:

$\mathrm{V}_{R}=2 f_{0} L$

where $V_{R}$ is the weighted mean acoustic velocity of the log $(\mathrm{m} / \mathrm{s}), f_{0}$ is the first harmonic frequency of an acoustic wave signal (Hz), and $L$ is the length of the $\log (\mathrm{m})$ (Wang 2013). Significant differences in the recorded velocities exist between the two techniques, with the resonance-based approach on $\operatorname{logs}$ being more accurate because it measures hundreds of waves instead of just the fastest wave (Mora et al. 2009; Wang 2013).

Ross et al. (1997) found moderate relationships between $\log$ and lumber MOE in balsam fir (Abies balsamea) $\left(R^{2}=0.33\right)$ but found excellent relationships for white spruce (Picea glauca) $\left(R^{2}=0.82\right)$. Wang et al. (2002) found moderate correlations between whole $\log \mathrm{MOE}$ as determined by static bending and dynamic log MOE as determined using acoustics for jack pine (Pinus banksiana) $\left(R^{2}=0.60\right)$ and red pine (Pinus resinosa) $\left(R^{2}=0.53\right)$. Vikram et al. (2011) found in Douglas-fir (Pseudotsuga menziesii) a moderate correlation $\left(R^{2}=0.42\right)$ between static bending MOE and log acoustic velocity in $2 \times 4$ Douglas-fir lumber. Wang et al. (2013) found a similar relationship in Douglas-fir $\left(R^{2}=0.40\right)$ between dynamic lumber MOE and log acoustic velocity. Zhi-ru et al. (2013) found in poplar (Populus euramericana) laminated veneer lumber (LVL) that $\log$ velocity was significantly correlated to dynamic MOE of veneer $\left(R^{2}=0.88\right)$. Achim et al. (2011) found in trembling aspen (Populus tremuloides) that sorting logs using acoustics prior to processing logs into veneer would be useful in culling logs that produce veneer unsuitable for LVL.

Research has been conducted to improve the accuracy of the acoustic velocity models. One method is to measure green density instead of assuming that it is constant (Lasserre et al. 2009; Wang 2013). For felled logs, measuring green density can be estimated by collecting disks and determining specific gravity and moisture content (ASTM D2395 2014c); however, it is obvious that this cannot be done for standing trees. Density and moisture content information could be estimated from collecting cores from standing trees following ASTM D2395 (2014c) or utilizing X-ray densitometry to estimate basic density. Drilling resistance has shown good correlations with wood density (Isik and Li 2003; Ratcliffe et al. 2014) as has Pilodyn penetration depth (Chen et al. 2015). Wang et al. (2013) increased the accuracy of the acoustic models by incorporating $\log$ height information (i.e., $\log 1$ ) into their model and the linear model improved from $R^{2}=0.40$ to 0.67 . Time- 
domain reflectometry (TDR) could be used to rapidly predict wood moisture content (Dahlen et al. 2015) on both standing trees and felled logs; however, TDR requires that probes be semi-permanently installed deeply into the wood and thus it is better suited for applications where multiple measurements over time are of interest as opposed to quick single determinations.

Loblolly pine is a commercially important species; yet, no published studies are available that link acoustic velocity of logs to lumber quality. Studies are available that link acoustic velocity to small clear samples (Mora et al. 2009); however, we recently found poor correlations between the mechanical properties of small clear samples and full sized lumber samples (Butler et al. 2016b) further prompting studies that link acoustic velocity of logs to lumber. Given the decline in the design values for southern pine, of which loblolly pine is the major species harvested, there is a need to better sort logs by quality (Murphy and Cown 2015). Acoustic velocity is also currently used in breeding programs for loblolly pine, and breeders are interested in knowing what additional variables could be incorporated into breeding decisions for improved lumber quality. Hence, the primary goals of this study were to

1. Determine the relationships between acoustic velocity, green density, and basic density of logs.

2. Investigate the relationship between acoustic velocity of logs to lumber MOE and modulus of rupture (MOR) from intensively managed loblolly pine trees.

3. Compare models developed using acoustic velocity versus models developing using tree characteristics to determine which is more effective at predicting lumber mechanical properties.

4. Set acoustic velocity thresholds for logs in order to meet the lumber MOE design values.

\section{Materials and methods}

\subsection{Tree selection}

Trees used in the present study were harvested in 2013 within the Lower Coastal Plain near Brunswick, Georgia (Butler et al. 2016a). The stand and tree characteristics are listed in Table 1. A total of 93 trees fell from 5 stands with ages ranging from 24 to 33 with $\mathrm{SI}_{25}$ from 25.3 to $27.4 \mathrm{~m}$. The total volume of lumber within each stand was estimated from measured tree dimensions in each 0.4 ha plot. The total volume of lumber was then distributed into 5 -cm diameter classes. Tree selection across the diameter classes was conducted as a percentage of the volume within a given diameter class compared to the overall volume within the stand; thus, more large trees were sampled from diameter classes that contain more lumber volume than small trees. Trees with major defects such as cankers and forks were not included in the sampling process. The trees sampled from the stands were relatively similar with minor statistical differences in height, no differences in diameter at breast height, and some differences in live crown ratio.

Table 1 Stand and fell tree characteristics

\begin{tabular}{|c|c|c|c|c|c|c|c|c|c|c|c|}
\hline \multicolumn{8}{|l|}{ Stand } & \multicolumn{4}{|c|}{ Fell trees } \\
\hline Stand & Latitude & Longitude & Age & $\begin{array}{l}\text { Site } \\
\text { index } \\
(\mathrm{m})\end{array}$ & $\begin{array}{l}\text { Quadratic mean } \\
\text { diameter }(\mathrm{cm})\end{array}$ & $\begin{array}{l}\text { Trees per } \\
\text { hectare }\end{array}$ & $\begin{array}{l}\text { Basal area } \\
\left(\mathrm{m}^{2} / \mathrm{ha}\right)\end{array}$ & $\begin{array}{l}\text { Trees } \\
\text { fell }\end{array}$ & $\begin{array}{l}\text { Mean } \\
\text { height } \\
\text { (m) }\end{array}$ & $\begin{array}{l}\text { Mean diameter at } \\
\text { breast height }(\mathrm{cm})\end{array}$ & $\begin{array}{l}\text { Live } \\
\text { crown } \\
\text { ratio }\end{array}$ \\
\hline 1 & 31.118729 & -81.757379 & 24 & 27.4 & 29.2 & 721 & 49 & 21 & $\begin{array}{l}27.4 \\
\quad(1.19) \mathrm{a}\end{array}$ & $31.3(3.11) \mathrm{a}$ & $\begin{array}{c}0.63 \\
(0.06)- \\
a b\end{array}$ \\
\hline 2 & 31.408185 & -81.772966 & 25 & 27.1 & 30.1 & 415 & 30 & 19 & $\begin{array}{l}27.3 \\
\quad(1.17) \mathrm{a}\end{array}$ & $31.5(3.49) \mathrm{a}$ & $\begin{array}{l}0.58 \\
\quad(0.07) b\end{array}$ \\
\hline 3 & 31.189826 & -81.750544 & 26 & 25.6 & 31.9 & 442 & 35 & 18 & $\begin{array}{l}27.3 \\
\quad(0.98) \mathrm{a}\end{array}$ & $32.0(2.69) \mathrm{a}$ & $\begin{array}{l}0.61 \\
\quad(0.06) \mathrm{b}\end{array}$ \\
\hline 4 & 31.322529 & -81.595399 & 27 & 26.2 & 30.4 & 442 & 32 & 20 & $\begin{array}{l}26.2 \\
\quad(1.70) b\end{array}$ & $31.8(3.32) \mathrm{a}$ & $\begin{array}{l}0.63 \\
\quad(0.05)- \\
a b\end{array}$ \\
\hline 5 & 31.344459 & v81.652424 & 33 & 25.3 & 33.0 & 208 & 18 & 9 & $\begin{array}{l}27.5 \\
\quad(0.64) \mathrm{a}\end{array}$ & $33.2(3.20) \mathrm{a}$ & $\begin{array}{l}0.69 \\
\quad(0.04) a\end{array}$ \\
\hline Overall & & & & & & & & 87 & $\begin{array}{l}27.1 \\
\quad(1.31)\end{array}$ & $31.8(3.22)$ & $\begin{array}{l}0.62 \\
\quad(0.07)\end{array}$ \\
\hline
\end{tabular}

Standard deviations are given in parenthesis

Letters denote significant differences $(\alpha<0.05)$ by Tukey test for height, diameter at breast height, and live crown ratio 


\subsection{Measurements on trees, logs, and lumber}

After felling, each tree was de-limbed; the total height and the height to live crown were measured. The top of the tree was cut to leave a $15.6-\mathrm{m}$ "tree-length" $\log$. Acoustic velocity of the tree-length log was measured using a HITMAN HM200 (Fiber-gen Limited, Christchurch, New Zealand). The treelength log was then bucked into 5.2-m logs numbered 1 (butt), 2 (middle), and 3 (top), with the acoustic velocity for each numbered $\log$ then measured. From the original 93 fell trees, 87 tree-length logs and 244 lumber-length logs yielded reliable acoustic velocity data whereby 3 consecutive readings had the same velocity, as well as lumber having no missing MOE data (i.e., deflectometer problems). Most logs yielded reliable acoustic velocity information without difficulty; however, logs with significant sweep required strategic placement of the sensor.

The outside diameter small-end diameter, mid-point diameter, and large-end diameter were measured from each log twice and then averaged. A $2.5-\mathrm{cm}$ disk was cut from the butt and top of each log and placed in a plastic bag; disks were then stored in a freezer at the wood quality laboratory (Athens, GA). The lumber-length logs were greater than the $5.03 \mathrm{~m}$ length required by the mill after extracting the disks. The diameter outside bark was measured for each disk using a diameter tape. The outer and inner bark was then peeled off carefully with a chisel, and then, a diameter tape was used to measure the diameter inside bark. The small-end diameter (SED) and large-end diameter (LED) inside bark measurements for each bolt, and the proportion of bark, were then used to adjust the outside bark mid-point diameter to inside bark mid-point diameter (MPD) for each $\log$. Taper $(\mathrm{cm} / \mathrm{m})$ was determined on each log via:

Taper $=\frac{L E D-S E D}{\text { length }}$

where LED is the large end diameter (cm), SED is the small end diameter $(\mathrm{cm})$, and length is the length $(\mathrm{m})$ of the log.

The lumber-length logs were transported to the participating mill (Hoboken, GA) and processed into $38.1 \mathrm{~mm}$ thick and $89 \mathrm{~mm}(2 \times 4), 140 \mathrm{~mm}(2 \times 6), 184 \mathrm{~mm}$ $(2 \times 8)$, and $235 \mathrm{~mm}(2 \times 10)$ wide lumber. Total number of lumber-length $\operatorname{logs}$ were 83 for $\log 1$ (butt), 84 for $\log 2$ (middle), and 77 for $\log 3$ (top). The lumber was kilndried, planed, and visually graded into No. 1 and better (No. 1), No. 2, and No. 3 by certified graders from the cooperating mill. During processing, the lumber was tracked such that each piece could be tied back to a specific stand, tree, $\log$, and location within a log. Altogether, the $244 \operatorname{logs}$ yielded a total of 780 pieces of lumber after grading; for the $89,140,184$, and $235 \mathrm{~mm}$ sizes, the respective counts of lumber pieces were 111, 279, 330, and 60 .
Separating the lumber by grade gave 153,561 , and 66 pieces for No. 1, No. 2, and No. 3 grades, respectively.

Testing of the lumber was conducted at the wood quality laboratory (Athens, GA). First, the air-dry density and acoustic velocity of each piece of lumber were measured. The lumber was then tested in static edgewise destructive bending according to ASTM D198 (2014a) and ASTM D4761 (2013) via four-point bending setup in third-point loading (load heads positioned one third of the span distance from the reactions) on a universal testing machine. The span to depth ratio was 17 to 1 ( $89 \mathrm{~mm}$ : 1511 to $89 \mathrm{~mm} ; 140 \mathrm{~mm}$ : 2375 to $140 \mathrm{~mm}$; $184 \mathrm{~mm}: 3131$ to $184 \mathrm{~mm} ; 235 \mathrm{~mm}$ : 3994 to $235 \mathrm{~mm}$ ). The lumber values were adjusted to $15 \%$ moisture content (ASTM D1990 2014b). For more details on the lumber testing, refer to Butler et al. (2016a, b). From each disk, green density and basic density were determined with the volume being determined via water immersion and the ovendry weight determined by oven-drying at $103 \pm 2{ }^{\circ} \mathrm{C}$ (ASTM D2395 2014c). The density of each disk was then used to reconstruct an estimate of the density of each log, using one disk cut from the bottom and one disk cut from the top of each log. Thus, the tree-length log used 4 disks, based on each disk's relative volume, with the top disk of the first log being the same as the bottom disk for the second log, and the same applied to the second and third log.

\subsection{Statistical analysis}

The statistical analysis and associated graphics were done in $\mathrm{R}$ statistical software (R Core Team 2016) with RStudio interface (RStudio 2016) and the packages dplyr (Wickham and Francois 2015), extrafont (Chang 2014), ggplot2 (Wickham 2009), grid (Wickham 2009), gridExtra (Auguie 2016), lme4 (Bates et al. 2015), lmerTest (Kuznetsova et al. 2016), multcomp (Hothorn et al. 2008), nlme (Pinheiro et al. 2016), and pROC (Robin et al. 2011). The mean, standard deviation, and range of the values were calculated for each variable. The mean and weighted mean MOE, MOR, and grade were determined for each tree-length and lumber-length $\log$. An analysis of variance for linear mixed effects models were conducted to test the effect of log location with stand and tree as random factors, and a Tukey test was used to conduct multiple comparisons between log location. A random effects models were used to determine the percentage of variation in SG, MOE, and MOR that was attributed to site, tree within site, log within tree, and the remaining within log variation. A 0.05 significance level was used for all the tests. The coefficient of determination $\left(R^{2}\right)$ and root mean square error (RMSE) were determined for linear and multiple linear regression models. Models with coefficient of determinations less than 0.10 were considered not practically significant. The area under the curve (AUC) of receiver operator characteristic (ROC) curves was calculated for tree and log acoustic properties and MOE. 
The AUC is the probability that the lumber produced from a tree or $\log$ will be correctly assigned to meeting the design values (0) or not meeting the design values (1). When AUC is 1 , it indicates a perfect prediction, and when the AUC is 0.5 , it indicates a random prediction (Hanley and McNeil 1982). The Select Structural (12.4 GPa), No. 1 grade (11.0 GPa), and No. 2 grade $(9.7 \mathrm{GPa}) \mathrm{MOE}$ design values were used for the ROC analysis and demonstrating the effect of acoustic velocity segregation via specified threshold values on the lumber MOE values, and the proportion of the logs that meet these acoustic velocity values.

\section{Results and discussion}

\subsection{Log properties}

The small end diameter, acoustic velocity, green density, and basic density measurements for the tree-length and lumberlength logs are presented in Table 2. This data shows that $\log 3$ (top) had significantly lower ( $p$ value $<0.0001$ ) acoustic velocity $(3219 \mathrm{~m} / \mathrm{s})$ compared to $\log 1(3425 \mathrm{~m} / \mathrm{s})$ and $\log 2$ $(3423 \mathrm{~m} / \mathrm{s})$. The tree-length log reading encompasses the third log and thus will also generally have a lower acoustic velocity than from the combined data from logs 1 and 2 (not shown), as well as $\operatorname{logs} 1$ or 2 on an individual basis. As to be expected, the mean acoustic velocity of the tree-length $\operatorname{logs}(3352 \mathrm{~m} / \mathrm{s})$ was very similar to the mean acoustic velocity when the data from all the lumber-length logs were pooled $(3358 \mathrm{~m} / \mathrm{s})$.

The data for the green density showed differences between $\log 1$ and $\operatorname{logs} 2$ and 3. Logs were significantly different with regard to basic density. Plotting the data for the tree-length (Fig. 1) and lumber-length logs (Fig. 2) showed considerable variation in the scatterplots of acoustic velocity, green density, and basic density. Green density was not correlated with acoustic velocity for either the tree-length $\left(R^{2}=0.01\right)$ or lumber-length $\operatorname{logs}\left(R^{2}=0.02\right)$, nor was it well correlated with basic density for the tree-length $\left(R^{2}=0.11\right)$ or the lumberlength $\operatorname{logs}\left(R^{2}=0.13\right)$. With basic density, a moderate relationship to acoustic velocity was evident for both tree-length $\operatorname{logs}\left(R^{2}=0.50\right)$ and lumber-length $\operatorname{logs}\left(R^{2}=0.42\right)$.

\subsection{Lumber properties}

The breakdown of lumber produced by stand and log number is shown in Table 3. For each stand, approximately the same number of lumber pieces were produced from the first $(N=292)$ and second $\log (N=290)$ with the third log producing a lower piece count $(N=198)$. The larger logs at the butt produced wider lumber than the second or third log. The breakdown of lumber grade by log shows that lumber grade decreases moving away from the butt log. Log 1 produced lumber with $35 \%$ No. 1 grade, $61 \%$ No. 2 grade, and $4 \%$

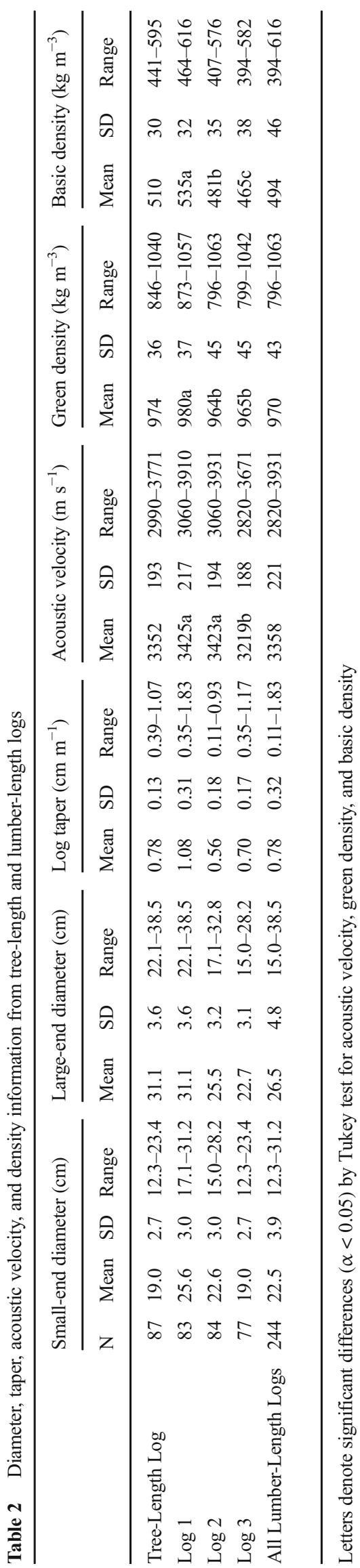


Fig. 1 Relationships between tree-length log acoustic velocity, green density, and basic density. The regression line (solid black line) is shown along with the $95 \%$ confidence interval of the mean (gray polygon around black line)
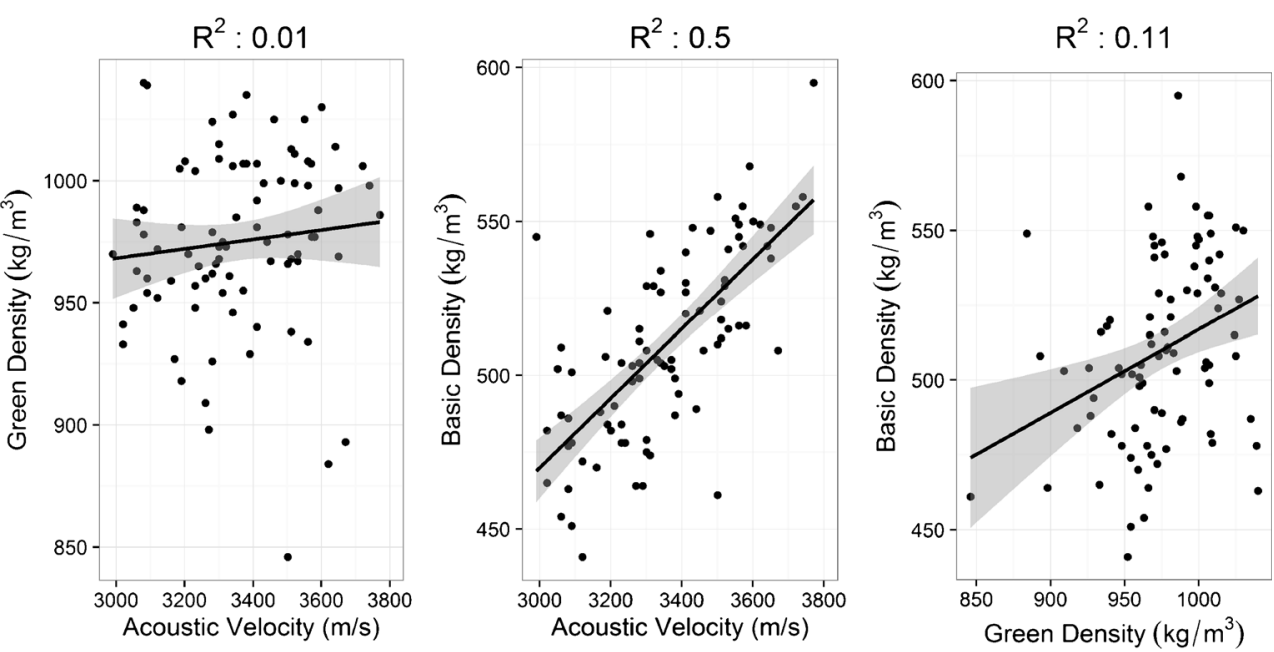

No. 3 grade. Log 2 produced lumber with $12 \%$ No. 1 grade, $80 \%$ No. 2 grade, and $8 \%$ No. 3 grade. Log 3 produced lumber with $9 \%$ No. 1 grade, $76 \%$ No. 2 grade, and $15 \%$ No. 3 grade. Stand 3 (age 26, 11.6 GPa) and stand 5 (age 33, 11.9 GPa) had comparable MOE values and were higher than stand 1 (age 24, 10.2 GPa), stand 2 (age 25, $10.1 \mathrm{GPa}$ ), and stand 4 (age 27, 10.6 GPa).

The MOE histogram by lumber grade (Nos. 1, 2, and 3) is shown in Fig. 3. The mean and weighted mean acoustic velocity, air dry density, MOE, and MOR lumber properties were calculated on the basis of the tree-length logs, the lumberlength logs, and pooled data for the lumber-length logs. The mean and weighted mean properties were similar, and only mean values will be discussed. The general trend for all lumber properties, except for acoustic velocity, is a reduction in lumber quality when moving up the stem (Table 4). The lumber from the $\log 2$ had significantly higher acoustic velocity $(4646 \mathrm{~m} / \mathrm{s})$ than $\log 1(4537 \mathrm{~m} / \mathrm{s})$ while the lumber from $\log 1$ was not significantly different from $\log 3(4535 \mathrm{~m} / \mathrm{s})$.
Regarding the sources of variation for the tree-length logs, for basic density, $17 \%$ of the variation was due to the stand, $15 \%$ was due to tree within the stand, and the remaining $68 \%$ was attributed to the within $\log$ variation. For MOE, $11 \%$ of the variation was due to the stand, $13 \%$ was due to tree within the stand, and the remaining $76 \%$ was attributed to the within $\log$ variation. For MOR, $5 \%$ of the variation was due to the stand, $8 \%$ was due to tree within the stand, and the remaining $87 \%$ was attributed to the within $\log$ variation. For the lumberlength logs, for basic density, $23 \%$ of the variation was due to the stand, $27 \%$ was due to tree within the stand, $4 \%$ was due to the $\log$ within the tree, and the remaining $46 \%$ was attributed to the within $\log$ variation. For MOE, $14 \%$ of the variation was due to the stand, $17 \%$ was due to tree within the stand, $10 \%$ was due to the log within the tree, and the remaining $59 \%$ was attributed to the within $\log$ variation. For MOR, $6 \%$ of the variation was due to the stand, $10 \%$ was due to tree within the stand, $0 \%$ was due to the log within the tree, and the remaining $84 \%$ was attributed to the within log variation.
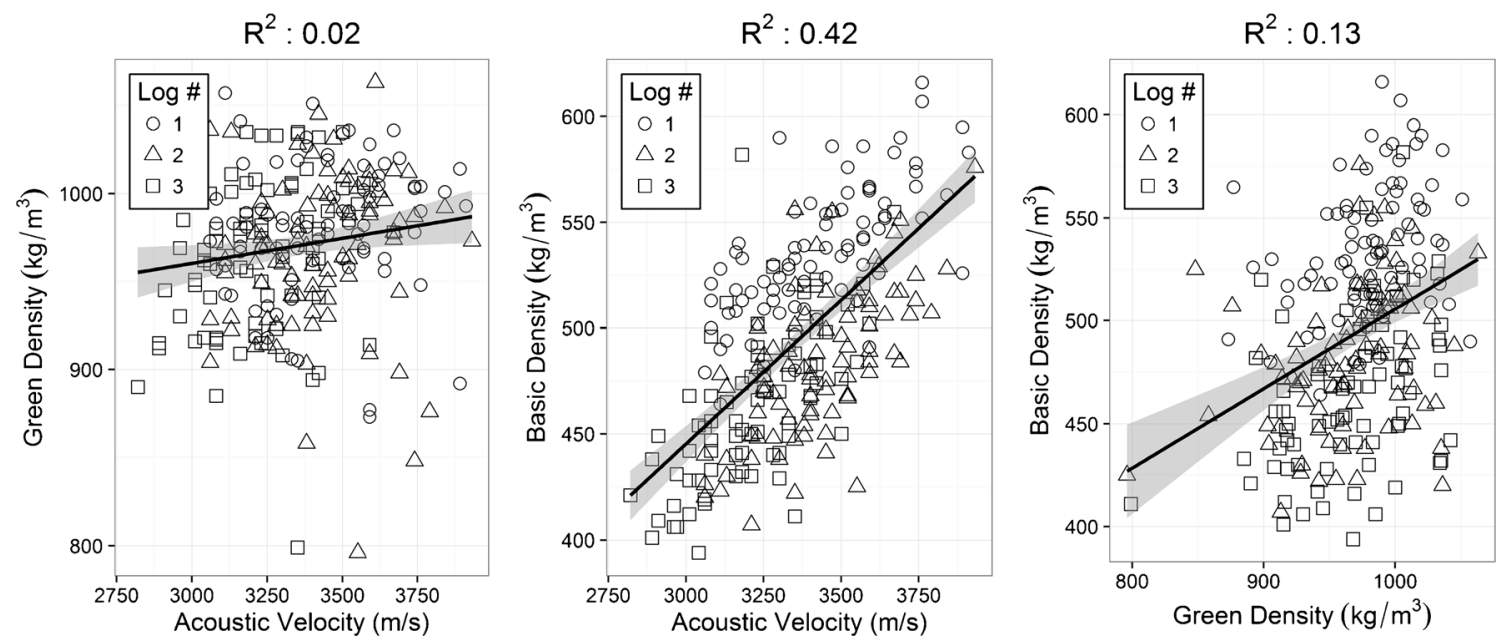

Fig. 2 Relationships between lumber-length log acoustic velocity, green density, and basic density. The regression line (solid black line) is shown along with the $95 \%$ confidence interval of the mean (gray polygon around black line) 
3.3 Modeling mean lumber modulus of elasticity from log properties

The relationships between mean lumber MOE with acoustic velocity and basic density are presented in Table 5 for the treelength logs and Table 6 for the lumber-length logs. Overall, acoustic velocity of a tree-length $\left(R^{2}=0.53\right.$, RMSE $=0.90 \mathrm{GPa})$ or lumber-length $\log \left(R^{2}=0.49\right.$, $\mathrm{RMSE}=1.37 \mathrm{GPa}$ ) had a reasonably good fit with predicting the mean lumber MOE (Fig. 4). Measured basic density of the $\log$ also resulted in a model that also had a reasonably good fit for tree-length $\operatorname{MOE}\left(R^{2}=0.32, \mathrm{RMSE}=1.08 \mathrm{GPa}\right)$ or lumber-length $\operatorname{MOE}\left(R^{2}=0.42, \mathrm{RMSE}=1.45 \mathrm{GPa}\right)$, but the model was not as accurate as the acoustic velocity model. Green density was not effective at predicting mean lumber MOE for tree-length $\left(R^{2}=0.11\right)$ or lumber-length $\left(R^{2}=0.10\right)$ models. Modeling mean lumber MOE solely with $\log$ position had similar results to basic density and was less accurate than acoustic velocity $\left(R^{2}=0.33\right.$, $\mathrm{RMSE}=1.55 \mathrm{GPa}$ ). Incorporating $\log$ position into the acoustic velocity or basic density model improved both the lumberlength acoustic velocity model $\left(R^{2}=0.62\right.$, RMSE $\left.=1.18\right)$ and the basic density model $\left(R^{2}=0.48\right.$, RMSE $\left.=1.37\right)$. The log position was the only tree variable that had a regression model with decent performance $\left(R^{2}>0.20\right)$. For the tree-length logs, no tree variable was practically significant, and for the lumberlength logs, only the diameter of the logs (small-end, midpoint, and large-end diameter) yielded semi-effective linear models $\left(R^{2}=0.12\right.$ to 0.17$)$. Other tree attributes such as height, DBH, live crown ratio, height to live crown, and largest branch diameter were not practically significant or not significant variables. Incorporating basic density of the log into the acoustic velocity model did not result in significant improvement over just using acoustic velocity for the treelength model; however, green density and acoustic velocity did result in an improved model for the tree-length logs $\left(R^{2}=0.59, \mathrm{RMSE}=0.83\right)$. Incorporating basic density in a model with acoustic velocity resulted in an improved model $\left(R^{2}=0.55, \mathrm{RMSE}=1.27\right)$ as did green density $\left(R^{2}=0.53\right.$, RMSE $=1.30$ ). The most accurate tree-length MOE model utilized the combination of acoustic velocity, green density, and mid-point diameter of the stem $\left(R^{2}=0.62, \mathrm{RMSE}=0.80\right)$. The most accurate lumber-length MOE model was similar to the tree-length model with the added variable of log number, and the small-end diameter led to a better fit than mid-point diameter $\left(R^{2}=0.67\right.$, RMSE $\left.=1.09\right)$.

The relationships between mean lumber MOR with acoustic velocity and basic density are presented in Table 5 for treelength and Table 6 lumber-length logs. Overall, measuring acoustic velocity on a tree-length $\left(R^{2}=0.16\right.$, RMSE $=5.80 \mathrm{MPa})$ or lumber-length $\log \left(R^{2}=0.20\right.$, $\mathrm{RMSE}=8.6 \mathrm{MPa}$ ) did not result in a model with a good fit for explaining mean lumber MOR (Fig. 5). Similarly, poor 
Fig. 3 Density histogram showing No. 1 grade (solid line), No. 2 grade (dashed line), and No. 3 grade (dotted line) distribution for modulus of elasticity (MOE) (GPa)

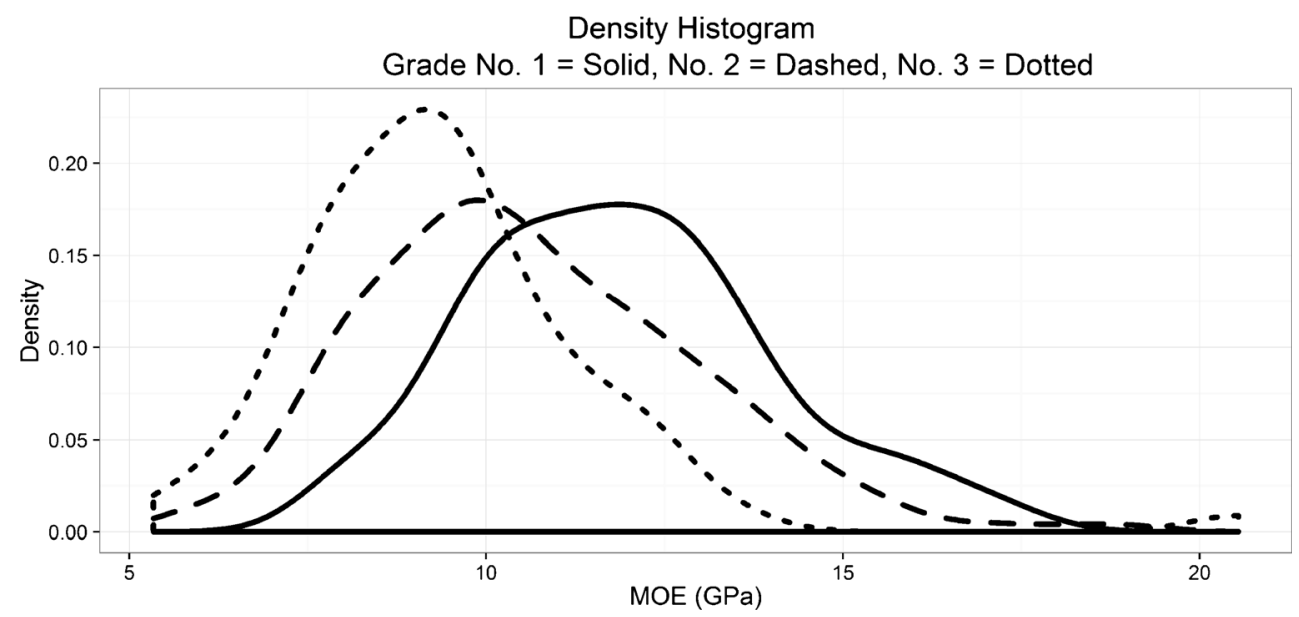

results with basic density for tree-length $\left(R^{2}=0.08\right.$, RMSE $=6.04 \mathrm{MPa})$ or lumber-length $\log \left(R^{2}=0.27\right.$, RMSE $=8.21 \mathrm{MPa}$ ) were obtained. The basic density treelength model was not practically significant $\left(R^{2}<0.10\right)$. Modeling mean lumber MOR solely with log position had slightly improved results compared to the acoustic velocity and basic density models $\left(R^{2}=0.31\right.$, RMSE $\left.=7.93 \mathrm{MPa}\right)$. Incorporating log position into the model improved the lumber-length acoustic velocity model $\left(R^{2}=0.40\right.$, RMSE $=7.41)$ and the basic density model $\left(R^{2}=0.35\right.$, RMSE $=7.70$ ). Similar to the MOE models, use of nonwood quality data was not useful for predicting MOR for tree-length logs and not useful for predicting lumber-length logs. The most accurate tree-length MOR model utilized the combination of acoustic velocity and green density $\left(R^{2}=0.18\right.$, RMSE = 5.63); however, the model performance was not good. The most accurate lumber-length MOR model was similar to the tree-length model with the added variable of $\log$ height $\left(R^{2}=0.42\right.$, RMSE $\left.=7.26\right)$.

\subsection{Acoustic velocity threshold values for meeting modulus of elasticity design values}

For the tree-length logs, 10 out of $87(11 \%)$ logs met the MOE design value for the Select Structural grade (12.4 GPa), 40 out of $87(46 \%)$ met the No. 1 grade (11.0 GPa), and 66 out of 87
(76\%) met the No. 2 grade $(9.7 \mathrm{GPa})$. Using the regression coefficients for the tree-length logs found in Table 4 $(\mathrm{MOE}=-5.94 * 0.005 * \mathrm{AV})$, we predicted the MOE using acoustic velocity and compared the results to the actual MOE measured, and then, we calculated the area under the curve for the receiver operator characteristic plots. The AUC for the Select Structural grade $(\mathrm{AUC}=0.95)$, No. 1 grade $(0.87)$, and No. 2 grade $(0.85)$ indicates that these measures have good accuracy at segregating tree-length logs that meet $(0=$ yes $)$ or do not meet the design values $(1=$ no $)$ for the respective grades. Setting a threshold velocity of $3170 \mathrm{~m} / \mathrm{s}$ would result in the remaining tree-length logs to produce lumber that met the No. 1 (11.0 GPa) MOE design value (Fig. 6). The $3170 \mathrm{~m} / \mathrm{s}$ threshold would exclude $19 \%$ of the tree-length logs, and not all of the remaining trees would produce lumber that meets the $11.0 \mathrm{GPa}$ design value; however, it does result in excluding a sufficient number of trees that produced lower MOE lumber that the mean value would increase from $10.7 \mathrm{GPa}$ to the $11.0 \mathrm{GPa}$ value. Setting this threshold did not result in excluding any tree-length logs that produced lumber that exceed the $11.0 \mathrm{GPa}$ design value. Setting a threshold of $3600 \mathrm{~m} / \mathrm{s}$ would result in the lumber meeting the Select Structural (12.4 GPa) MOE design value, which would exclude $86 \%$ of the tree-length logs and $6 \%$ of the excluded logs did produce lumber that exceeded the 12.4 GPa MOE value and thus were improperly excluded.

Table 4 Physical and mechanical properties of the lumber from the tree-length and lumber-length logs

\begin{tabular}{|c|c|c|c|c|c|c|c|c|c|c|c|c|c|}
\hline & \multicolumn{4}{|c|}{ Acoustic velocity (m/s) } & \multicolumn{3}{|c|}{ Basic density $\left(\mathrm{kg} / \mathrm{m}^{3}\right)$} & \multicolumn{3}{|c|}{ Modulus of elasticity (GPa) } & \multicolumn{3}{|c|}{ Modulus of rupture (MPa) } \\
\hline & $\mathrm{N}$ & Mean & $\mathrm{SD}$ & Range & Mean & $\mathrm{SD}$ & Range & Mean & $\mathrm{SD}$ & Range & Mean & $\mathrm{SD}$ & Range \\
\hline Tree-length log & 89 & 4584 & 204 & $4135-5006$ & 574 & 36 & $496-675$ & 10.7 & 1.3 & $8.1-13.7$ & 40.1 & 6.6 & $27.7-57.1$ \\
\hline $\log 1$ & 83 & $4537 \mathrm{~b}$ & 289 & $3829-5077$ & $614 \mathrm{a}$ & 42 & $506-717$ & $11.9 \mathrm{a}$ & 1.9 & $7.9-16.1$ & $46.3 \mathrm{a}$ & 9.2 & $25.3-67.1$ \\
\hline $\log 2$ & 84 & $4646 a$ & 226 & $4025-5100$ & $561 b$ & 40 & $483-692$ & $10.6 b$ & 1.4 & $7.7-14.6$ & $37.3 b$ & 6.7 & $25.1-56.1$ \\
\hline $\log 3$ & 77 & $4535 b$ & 224 & $4035-5090$ & $534 \mathrm{c}$ & 38 & $439-653$ & $9.1 \mathrm{c}$ & 1.4 & $5.7-12.7$ & $33.6 \mathrm{c}$ & 8.1 & $16.8-56.8$ \\
\hline All lumber-length logs & 244 & 4573 & 253 & $3829-5100$ & 570 & 52 & $439-717$ & 10.5 & 1.9 & $5.7-16.1$ & 39.1 & 9.7 & $16.8-67.1$ \\
\hline
\end{tabular}

Letters denote significant differences $(\alpha<0.05)$ for log means by Tukey test 
Table 5 Relationships between lumber modulus of elasticity and modulus of rupture for tree-length logs versus independent variables acoustic velocity, basic density, and log shape

\begin{tabular}{llll}
\hline Tree-length logs & & & \\
\hline Variable & Equation and parameters & $R^{2}$ & RMSE \\
\hline MOE (GPa) & MOE $=-1.65+0.024 \mathrm{BD}$ & 0.32 & 1.08 \\
& $\mathrm{MOE}=-5.94+0.005 \mathrm{AV}$ & 0.53 & 0.90 \\
& $\mathrm{MOE}=-1.607+0.013 \mathrm{GD}$ & 0.11 & 1.23 \\
& $\mathrm{MOE}=-15.063+0.005 \mathrm{AV}+0.01 \mathrm{GD}$ & 0.59 & 0.83 \\
& $\mathrm{MOE}=-17.629+0.005 \mathrm{AV}+0.009 \mathrm{GD}+0.70 \mathrm{MPD}$ & 0.62 & 0.80 \\
$\mathrm{MOR}(\mathrm{MPa})$ & $\mathrm{MOR}=10.161+0.059 \mathrm{BD}$ & 0.08 & 6.04 \\
& $\mathrm{MOR}=-3.454+0.013 \mathrm{AV}$ & 0.16 & 5.80 \\
& $\mathrm{MOR}=-37.886+0.012 \mathrm{AV}+0.038 \mathrm{GD}$ & 0.18 & 5.63 \\
\hline
\end{tabular}

$M O E$ modulus of elasticity (GPa), MOR modulus of rupture (MPa), $A V$ acoustic velocity of HM-200 (m s ${ }^{-1}$ ), $B D$ basic density $\left(\mathrm{kg} \mathrm{m}^{-3}\right), G D$ green density $\left(\mathrm{kg} \mathrm{m}^{-3}\right), M P D$ mid-point diameter $(\mathrm{cm})$
For the lumber-length logs, 43 out of 244 (18\%) logs met the MOE design value for the Select Structural grade $(12.4 \mathrm{GPa}), 94$ out of $244(38 \%)$ met the No. 1 grade
$(11.0 \mathrm{GPa})$, and 151 out of $244(62 \%)$ met the No. 2 grade (9.7 GPa). Using the regression coefficients for the tree-length $\log _{\mathrm{s}}$ found in Table $4(\mathrm{MOE}=-9.687 * 0.006 * \mathrm{AV})$, we
Table 6 Relationships between lumber modulus of elasticity and modulus of rupture for lumberlength logs versus independent variables acoustic velocity, basic density, log shape, and log position

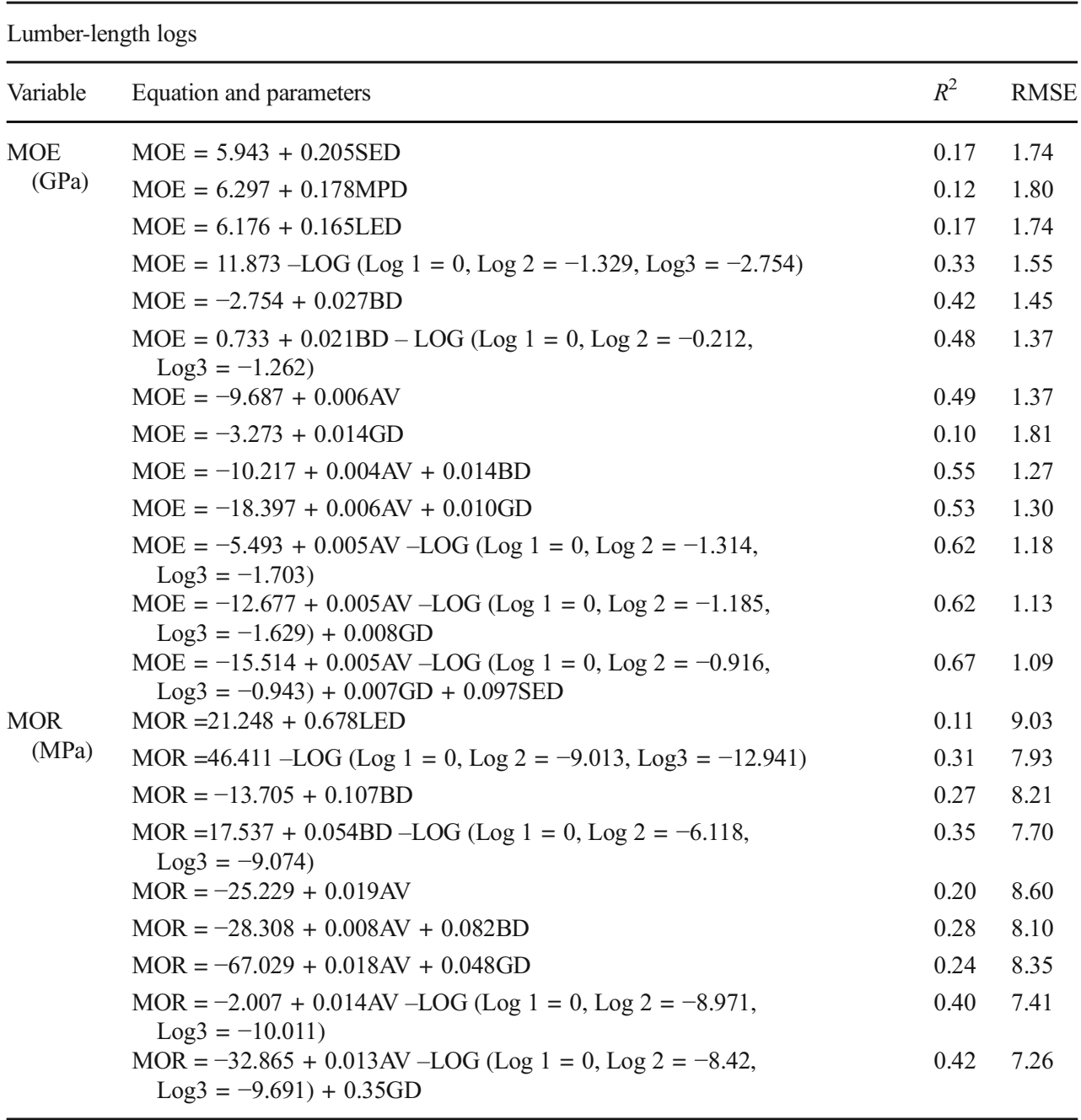

$M O E$ modulus of elasticity (GPa), $A V$ acoustic velocity of HM-200 $\left(\mathrm{m} \mathrm{s}^{-1}\right), B D$ basic density $\left(\mathrm{kg} \mathrm{m}^{-3}\right), G D$ green density $\left(\mathrm{kg} \mathrm{m}^{-3}\right), M P D$ mid-point diameter $(\mathrm{cm}), M O R$ modulus of rupture (MPa), SED small end diameter $(\mathrm{cm})$, $L E D$ large end diameter $(\mathrm{cm}), L O G \log$ number where parameter is different for logs 2 or 3 

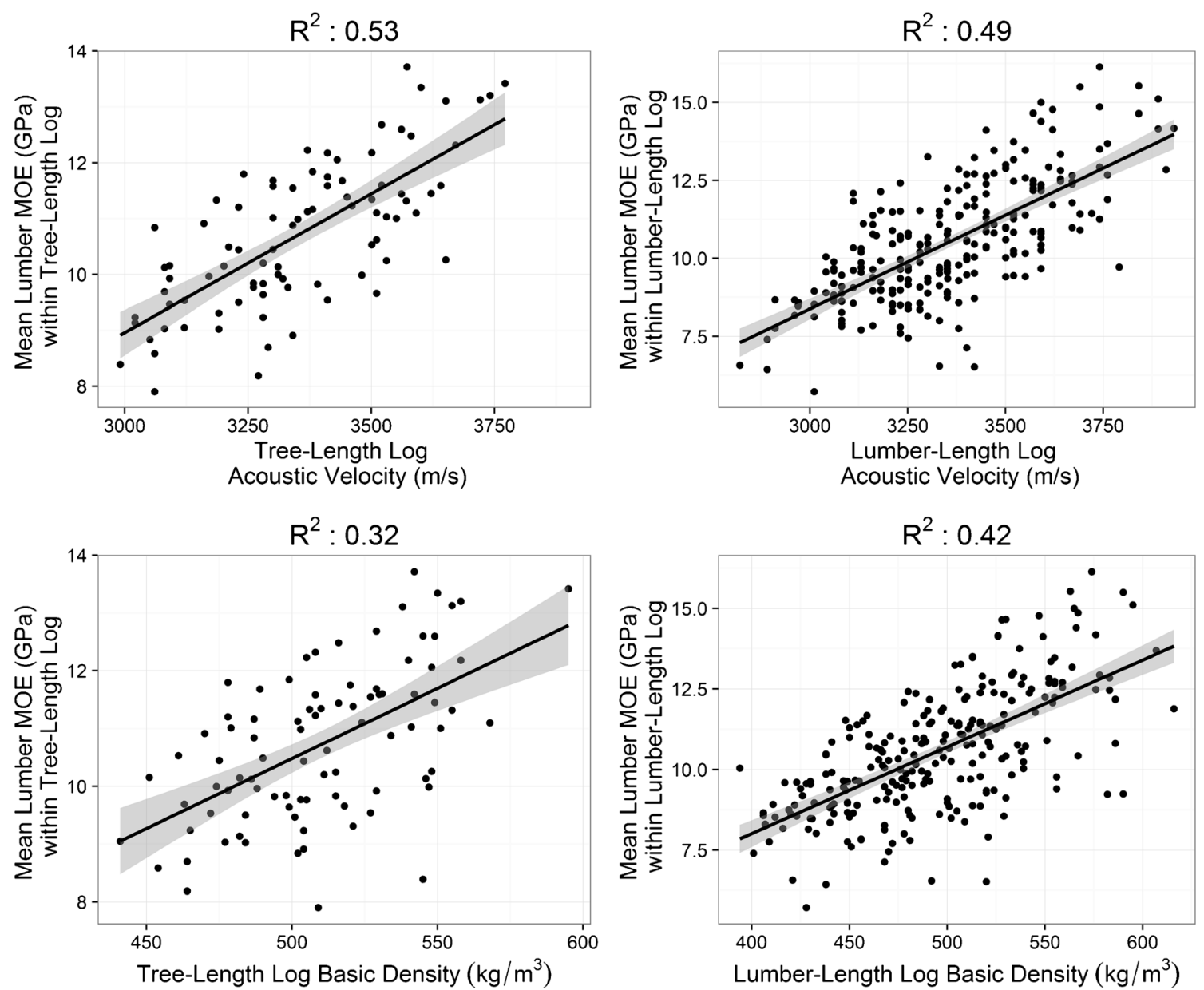

Fig. 4 Mean lumber static modulus of elasticity within tree-length and lumber-length log versus acoustic velocity or basic density. The regression line (solid black line) is shown along with the $95 \%$ confidence interval of the mean (gray polygon around black line)

predicted the MOE using acoustic velocity and compared the results to the actual MOE measured, and then, we calculated the area under the curve for the receiver operator characteristic plots. The AUC for the Select Structural grade $(\mathrm{AUC}=0.88)$, No. 1 grade (0.83), and No. 2 grade (0.84) indicates that these measures have good accuracy at segregating lumber-length logs that meet $(0=$ yes $)$ or do not meet the design values $(1=$ no) for the respective grades. A threshold of $3210 \mathrm{~m} / \mathrm{s}$ would result in the lumber meeting the No. 1 (11.0 GPa) MOE design value, which would exclude $27 \%$ of the lumber-length logs (Fig. 6) of which $3 \%$ of the logs did produce lumber with a MOE greater than or equal to $11.0 \mathrm{GPa}$ and thus were improperly excluded. A threshold of $3520 \mathrm{~m} / \mathrm{s}$ would result in the lumber meeting the Select Structural (12.4 GPa) MOE design value, which would exclude $76 \%$ of the lumberlength logs of which $5 \%$ of the logs did produce lumber with a MOE greater than or equal to $12.4 \mathrm{GPa}$ and thus were improperly excluded. Because the MOE of the lumber decreases with increasing log number, the threshold approach is also useful when looking at the individual log heights since a mill could saw lumber differently if the log came from the butt versus the top (Fig. 7). For $\log 1$, to meet the Select
Structural MOE design value (12.4 GPa), an acoustic velocity threshold of $3250 \mathrm{~m} / \mathrm{s}$ is needed which would exclude $25 \%$ of the logs of which $1 \%$ of the logs would be improperly excluded. For $\log 2$, to meet the No. 1 grade MOE $(11.0 \mathrm{GPa})$, an acoustic velocity threshold of $3330 \mathrm{~m} / \mathrm{s}$ is needed which would exclude $33 \%$ of the logs of which $4 \%$ of the logs would be improperly excluded. For $\log 2$, to meet the Select Structural grade, an acoustic velocity threshold of $3720 \mathrm{~m} / \mathrm{s}$ is needed which would exclude $92 \%$ of the logs of which $6 \%$ of the $\operatorname{logs}$ would be improperly excluded. For $\log 3$, to meet the No. 2 grade, an acoustic velocity threshold of $3280 \mathrm{~m} / \mathrm{s}$ is needed which would exclude $61 \%$ of the logs of which $8 \%$ of the $\log$ s would be improperly excluded. For $\log 3$, to meet the No. 1 grade, an acoustic velocity threshold of $3520 \mathrm{~m} / \mathrm{s}$ is needed which would exclude $93 \%$ of the logs of which $4 \%$ of the logs would be improperly excluded.

\section{Discussion}

Log 1 acoustic velocity ranged from 3060 to $3910 \mathrm{~m} / \mathrm{s}$ which is much higher than the range found by Mora et al. (2009) who 

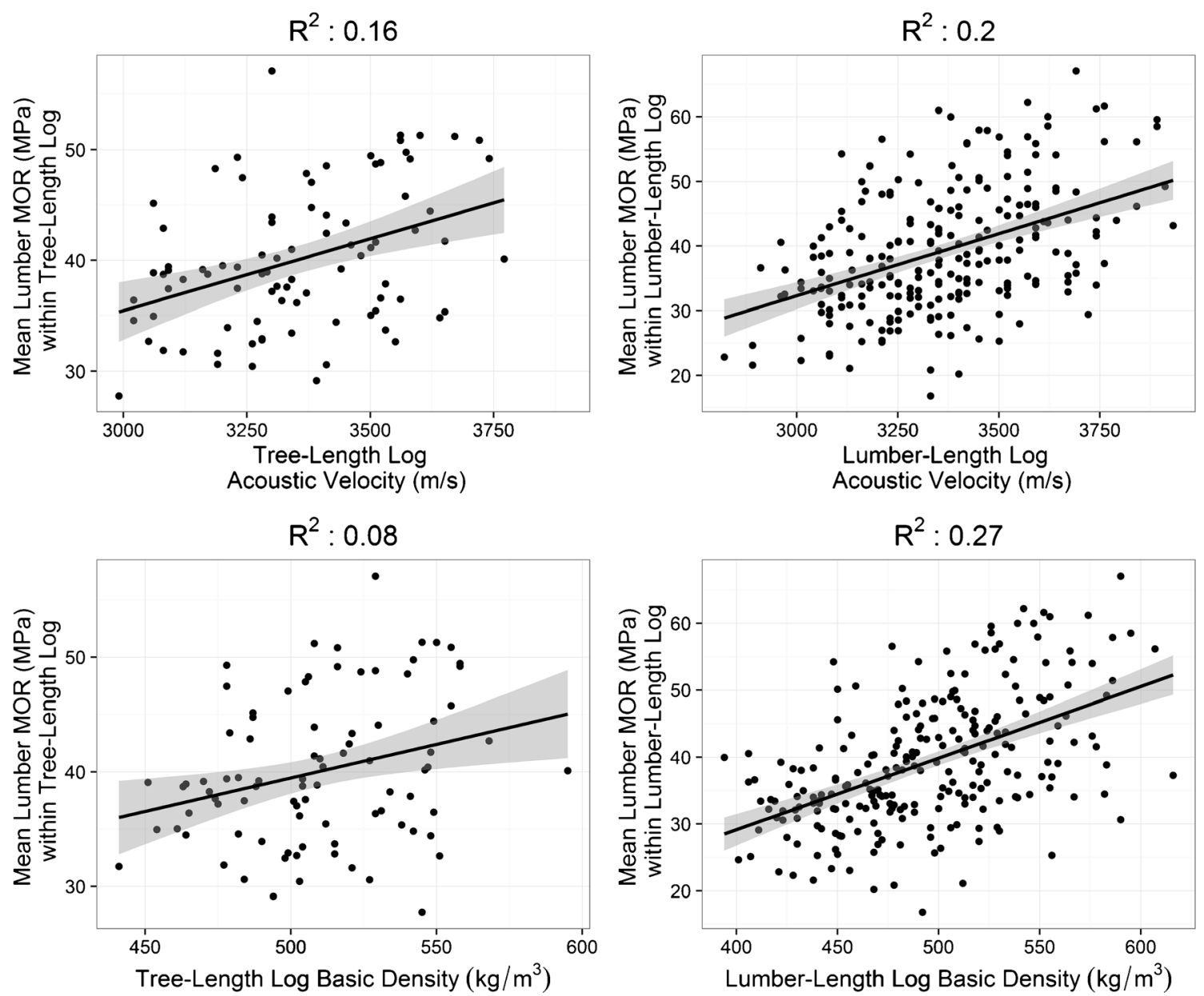

Fig. 5 Mean lumber modulus of rupture within tree-length and lumber-length log versus acoustic velocity or basic density. The regression line (solid black line) is shown along with the $95 \%$ confidence interval of the mean (gray polygon around black line)

Fig. 6 Effect of tree-length and lumber-length log segregation using the HM-200 on the mean lumber static modulus of elasticity within $\log$ (solid line). The dashed line indicates the proportion of logs that meet or exceed the acoustic velocity threshold. The horizontal dashed lines indicate the modulus of elasticity design value for the Select Structural (12.4 GPa) and No. 1 (11.0 GPa) grade

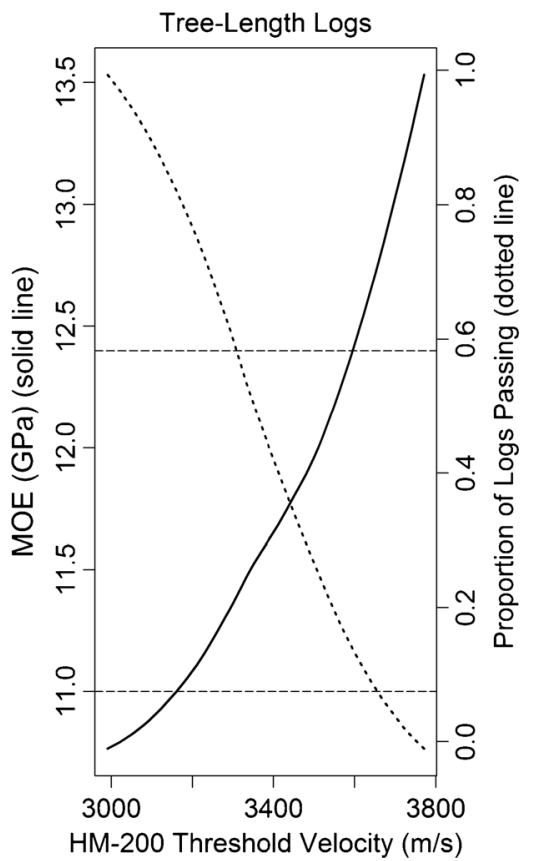

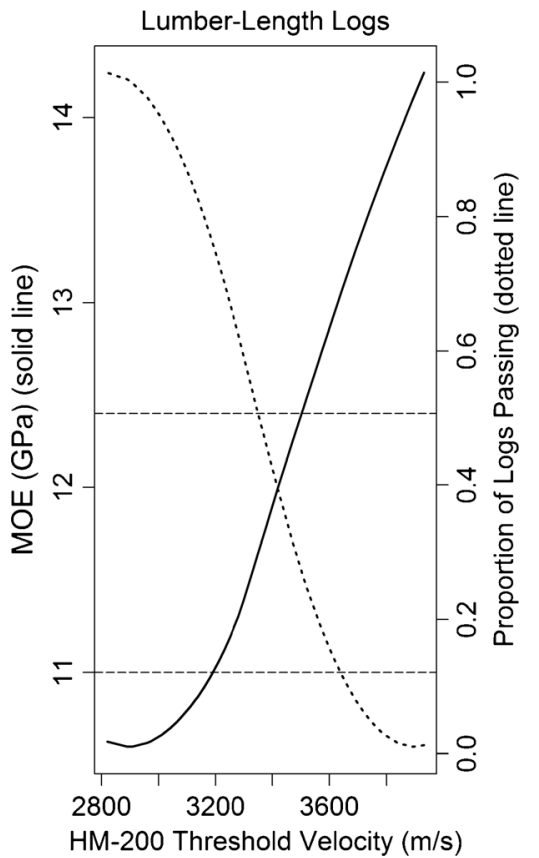




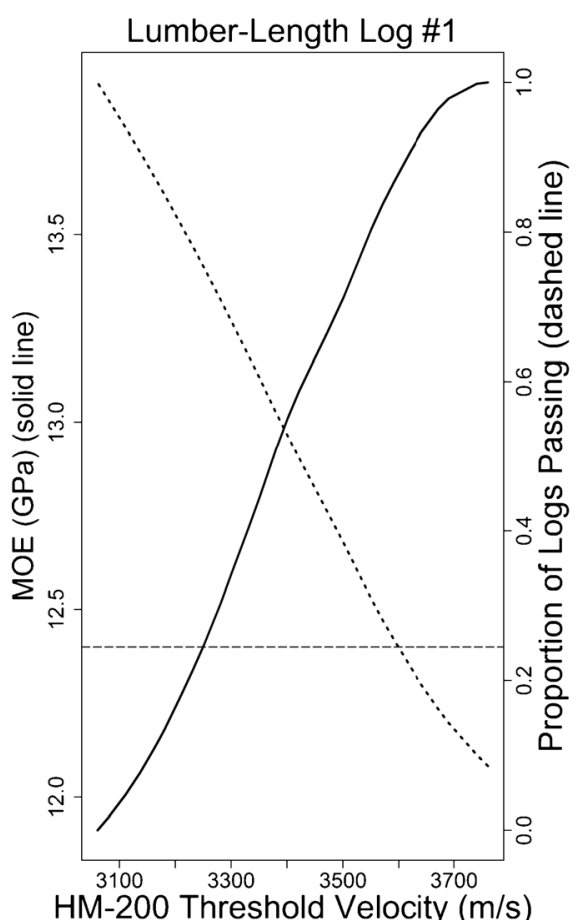

HM-200 Threshold Velocity $(\mathrm{m} / \mathrm{s})$

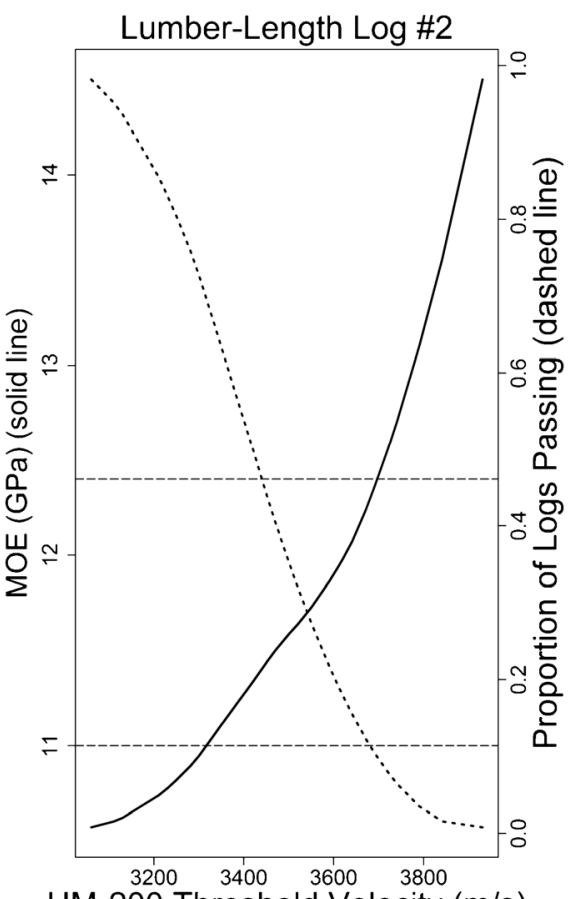

HM-200 Threshold Velocity $(\mathrm{m} / \mathrm{s})$
Lumber-Length Log \#3

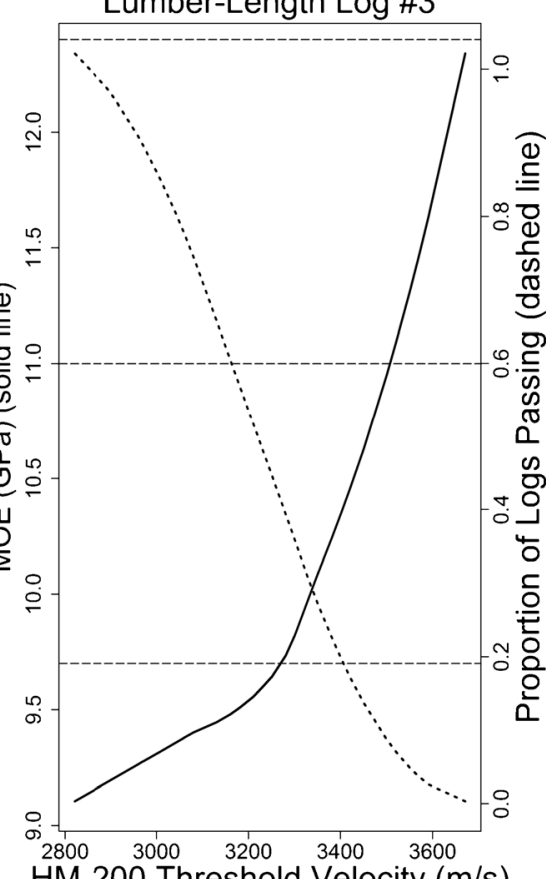

HM-200 Threshold Velocity $(\mathrm{m} / \mathrm{s})$
Fig. 7 Effect of lumber-length log segregation using the HM-200 on the mean lumber static modulus of elasticity within the first, second, and third $\log$ (solid line). The dashed line indicates the proportion of logs that meet or exceed the acoustic velocity threshold. The horizontal dashed lines indicate the modulus of elasticity design value for the Select Structural (12.4 GPa), No. 1 (11.0 GPa) grade, and No. 2 (9.7 GPa) grade found velocities from 1909 to $3228 \mathrm{~m} / \mathrm{s}$. The difference can be attributed to age whereby trees in this study were from 24 to 33 years old, whereas Mora et al. (2009) examined 15- to 19year-old loblolly pine trees. Mora et al. (2009) found strong relationships between tree and $\log$ velocity $\left(R^{2}=0.81\right)$. Moore et al. (2013) found for Sitka spruce good relationships between tree and log velocity $\left(R^{2}=0.71\right)$ at the stand level. It would have been interesting to know if the strong relationship held true for older loblolly pine trees with greater diameters, but unfortunately, our tree acoustic velocity meter failed during field sampling and there was not sufficient time to repair the instrument for use in the study.

The acoustic velocity of $\operatorname{logs} 1(3425 \mathrm{~m} / \mathrm{s})$ and $2(3423 \mathrm{~m} / \mathrm{s})$ were not significantly different from each other but were different from $\log 3(3219 \mathrm{~m} / \mathrm{s})$. The lower acoustic velocity for $\log 3$ is expected due to larger proportions of knots and juvenile wood in $\log 3$; in this study, $26 \%$ of the top $\operatorname{logs}(\log 3)$ contained the live crown. However, the acoustic velocity of the lumber sawn from $\log 2$ was significantly higher $(4646 \mathrm{~m} /$ s) than $\log 1(4537 \mathrm{~m} / \mathrm{s})$. The lower acoustic velocity of the lumber from the butt $\log (\log 1)$ may be due to processing the logs into lumber and the relatively high taper present near the butt of the stem. Thus, much of the higher density wood with lower microfibril angles was chipped instead of being converted into lumber. While the acoustic velocity of the lumber was lower from $\log 1$ than $\log 2$, the opposite was true for MOE of the lumber. Specifically, lumber from the butt $\log (11.9 \mathrm{GPa})$ had a mean MOE that was 1.3 GPa higher than lumber from the middle $\log (10.6 \mathrm{GPa})$. The difference in lumber MOE is likely due to both the higher lumber specific gravity for $\log 1$ ( 0.61 vs 0.56$)$ as well as the smaller knots typically found in $\log 1$. The lumber results are similar to results found by Wang et al. (2013) where MOE had a negative relationship with vertical log position $\left(R^{2}=0.58\right)$ in Douglas-fir (Pseudotsuga menziesii), meaning that log MOE decreased from the butt log to the crown.

We found considerable differences in the sources of variation of the lumber compared to what Moore et al. (2013) found for Sitka spruce (Table 7). Overall, we found more variation due to $\log$ position and variation within $\log$ than Moore et al. (2013) found, and less variation due to site and tree within site. The differences could be due to the sampling scheme where we harvested trees from stands that had little geographic variation and slight differences in age, whereas Moore et al. (2013) selected stands based on standing tree stiffness and had a greater range of ages (26 to 47 ). It could also be due to differences in Sitka spruce versus loblolly pine.

The results of the mean MOE lumber models show that acoustic velocity is a useful method for sorting tree$\left(R^{2}=0.53, \mathrm{RMSE}=0.90 \mathrm{GPa}\right)$ and lumber-length logs $\left(R^{2}=0.49\right.$, RMSE $\left.=1.37 \mathrm{GPa}\right)$. A mill could randomly sample logs on trucks to determine if logs met the predicted design values or values need for other mill products. Additionally, a mill could install an acoustic system prior to the headrig with the results influencing the sawing solution; alternatively, or in conjunction, a similar system could be installed at the gang 
Table 7 Comparison of variation sources for loblolly pine and Sitka spruce lumber (Moore et al. 2013)

\begin{tabular}{|c|c|c|c|c|c|c|}
\hline \multirow[t]{2}{*}{ Variation Source } & \multicolumn{2}{|l|}{$\begin{array}{l}\text { Density } \\
\left(\mathrm{kg} \mathrm{m}^{-3}\right)\end{array}$} & \multicolumn{2}{|c|}{$\begin{array}{l}\text { Modulus of Elasticity } \\
(\mathrm{GPa})\end{array}$} & \multicolumn{2}{|c|}{$\begin{array}{l}\text { Modulus of Rupture } \\
\text { (MPa) }\end{array}$} \\
\hline & Loblolly pine & Sitka spruce & Loblolly pine & Sitka spruce & Loblolly pine & Sitka spruce \\
\hline Site & $23 \%$ & $23 \%$ & $14 \%$ & $26 \%$ & $6 \%$ & $18 \%$ \\
\hline Tree within site & $27 \%$ & $51 \%$ & $17 \%$ & $36 \%$ & $10 \%$ & $25 \%$ \\
\hline Log within tree & $4 \%$ & $1 \%$ & $10 \%$ & $2 \%$ & $0 \%$ & $5 \%$ \\
\hline Within log & $46 \%$ & $25 \%$ & $59 \%$ & $36 \%$ & $84 \%$ & $52 \%$ \\
\hline
\end{tabular}

saw to account for the differences in log quality compared to cant quality. Thus, logs or cants with low acoustic velocity could be turned into posts, and higher acoustic velocity logs could be sawn in dimension lumber. The MOE design values for visually graded No. 1 and No. 2 southern pine lumber are 11.0 and $9.7 \mathrm{GPa}$, respectively. Based on these data, incoming tree-length logs would need to exceed 4150 and $3825 \mathrm{~m} / \mathrm{s}$, respectively, to meet the No. 1 and No. 2 MOE design values. For lumber-length logs, the acoustic velocity values would need to exceed 3400 and $3180 \mathrm{~m} / \mathrm{s}$, respectively, to meet the design values for MOE. This study was conducted in the summer on intensively managed material in the Lower Coastal Plain of Georgia, and thus, the equations would likely need to be modified to reflect a higher diversity of material that is utilized at mills, differences in sawing solutions, as well as seasonal differences in the wood moisture content. Prediction of MOR was more difficult because of the complex interactions that exist within a piece of lumber due to knot sizes, shapes, locations, and differences in slope of grain and specific gravity.

Both the mean MOE and MOR models were improved by adding log position to the acoustic velocity equation; however, where log position explained more of the variation in MOR than acoustic velocity, the opposite was true for MOE. Log position and log dimensions were the only useful non-wood quality type variables that were useful in predicting lumber MOE which differed from the Moore et al. (2013) study. Again, this could be due to species differences and the range of trees sampled in that study versus this one. Green density was useful for predicting lumber stiffness when combined with acoustic velocity and $\log$ position $\left(R^{2}=0.64\right.$, RMSE $=1.14 \mathrm{GPa}$ ). The addition of green density is interesting given that it was so poorly correlated with basic density, MOE, and MOR. A constant green density value of $1000 \mathrm{~kg} /$ $\mathrm{m}^{3}$ is typically used when acoustic tools are applied to either standing trees or logs, when calculating dynamic MOE. The differences observed in green density illustrate that this practice is not entirely appropriate. In this study, green and basic density of the logs were estimated from disks cut from the ends of the logs or 4 disks from the tree-length log, and thus, it is not known how accurate the estimate of basic density was throughout the entire log. Future tests that examine drilling resistance or Pilodyn penetration would be of value in loblolly pine given that they are both rapid measurements that relate to wood density.

Incorporating wood property evaluation into studies can be difficult given the relative cost associated with transporting samples back to the laboratory and performing any subsequent measurement on the samples. Comparatively, measuring acoustic velocity on logs is rapid and provides valuable information on the quality of the log. Overall, the acoustic velocity models had improved prediction performance compared to the basic density models. These factors suggest that many forest studies could incorporate acoustic velocity of tree-length and lumber-length logs at relatively little expense.

For the multiple regression models, log diameter measurements are typically measured in the field and thus feasible to incorporate into models. In mills, diameter measurements are routinely conducted via lasers which yield a complete picture of the $\log$ dimensions, and thus, mill equipment would likely yield more accurate models than the models developed here. In the field, measurements of live crown are routine but are not feasible at a mill. Mills could determine green density via weight measurements linked to the volume as determined by scanning, and thus, the accuracy would likely be increased over our predicted green density based on disks. In the field, measuring green density will likely continue to be relied on estimates based on disk information. The largest branch is relatively easy to collect in the field; however, there is a need to develop accurate, low cost, and rapid techniques for measuring branch characteristics in the field. At mills, branch information could be included into models based on the volume scans in logs where the branches have not been covered over by wood growth.

Of the variables examined here, acoustic velocity proved the most useful for segregating logs based on the resulting MOE of the lumber produced from them. However, the MOE models for the tree-length $\left(R^{2}=0.53\right.$, RMSE $=0.90 \mathrm{GPa})$ and lumber-length $\operatorname{logs}\left(R^{2}=0.49\right.$, RMSE $=1.37 \mathrm{GPa}$ ) suggest that 53 and $49 \%$ of the variation in lumber MOE is being accounted for by acoustic velocity; however, this is not the case because of the within log 
variation that exist because of pith to bark and stump to tip changes in wood properties. For the tree-length logs, $76 \%$ of variation for tree-length logs is found within the log; thus, segregation is only explaining $13 \%(53 \% *(100 \%-76 \%))$ of the variation in lumber properties. Likewise, for the lumberlength $\operatorname{logs}, 59 \%$ of the variation is found within the log, and thus, segregation is only explaining $20 \%$ of the total variation. Thus, any segregation strategy needs to balance the fact that lumber produced within logs will contain a mixture of lumber that will meet or not meet specified design values.

The segregation acoustic velocity values differ greatly from using the models to predict lumber MOE because of the variability in the prediction equation. For the tree-length models, a velocity value of $4150 \mathrm{~m} / \mathrm{s}$ is needed for the tree-length $\log$ to meet the $11.0 \mathrm{GPa}$ MOE design value for the No. 1 grade. However, for the logs sampled, a threshold value of $3170 \mathrm{~m} / \mathrm{s}$ would result in the remaining logs that were not excluded to produce lumber that overall met the $11.0 \mathrm{GPa}$ design value. The first approach would exclude $41 \%$ of the logs of which $31 \%$ were excluded improperly, whereas the segregation approach would exclude $19 \%$ of the logs and $0 \%$ of the logs were improperly excluded. For the lumber-length models, a velocity value of $3400 \mathrm{~m} / \mathrm{s}$ is needed for the lumber-length logs to meet the 11.0 GPa MOE design value for the No. 1 grade. However, for the logs sampled, a threshold value of $3210 \mathrm{~m} / \mathrm{s}$ would result in the remaining logs to produce lumber that overall met the $11.0 \mathrm{GPa}$ design value. The first approach would exclude $36 \%$ of the logs of which $33 \%$ were excluded improperly, whereas the segregation approach would exclude $27 \%$ of the logs and $3 \%$ of the logs were improperly excluded. Given variation from pith to bark and stump to tip that exists in logs, and the differences found in the lumber stiffness between log heights, perhaps the most practical situation would be to buck the stem into logs, and then change the sawing pattern for the top logs if they met specified thresholds. Over time, a mill could collect enough data to make informed decisions about the lumber properties of the logs prior to sawing which when coupled with information on the age and stand history of the logs could result in better informed procurement decisions.

\section{Conclusions}

The results from this study show that evaluating acoustic velocity of loblolly pine tree-length and lumber-length logs can be used to segregate logs for lumber modulus of elasticity. The utilization of acoustics is not dependent on knowing tree or stand information such as age, site quality, and silviculture history. The relatively ease of use means that tree-length and lumber-length $\operatorname{logs}$ for loblolly pine could be evaluated throughout the supply chain to give a better indicator of the resulting product quality. Wood properties have traditionally been expensive to measure and most tests are destructive. For mills, acoustics could be factored into sawing solution decisions thereby identifying higher velocity logs that could be sawn specifically to make smaller width machine stress rated lumber. Consequently, lower velocity logs could be turned into timbers that are then treated. Product sorting by mills could result in paying premium or reduced prices for logs that exceed or do not meet specifications, respectively.

Acknowledgements This research was possible through support from the Plum Creek Timber Company, the National Science Foundation (NSF) Center for Advanced Forest Systems (CAFS), McIntire-Stennis, and the Wood Quality Consortium (WQC) at the University of Georgia. The authors wish to thank Plum Creek Timber Company, NSF CAFS, and the WQC for funding this project. We gratefully acknowledge Varn Wood Products LLC for processing the logs into structural lumber. The authors gratefully thank the editor and reviewers at Annals of Forest Science for their helpful and insightful comments.

\section{References}

Achim A, Paradis N, Carter P, Hernández RE (2011) Using acoustic sensors to improve the efficiency of the forest value chain in Canada: a case study with laminated veneer lumber. Sensors 11: $5716-5728$

ASTM International (2013) ASTM D4761-13: Standard test methods for mechanical properties of lumber and wood-base structural material. West Conshohocken, PA

ASTM International (2014a) ASTM D198-14: Standard test methods of static tests of lumber in structural sizes. West Conshohocken, PA

ASTM International (2014b) ASTM D1990-14: Standard practice for establishing allowable properties for visually-graded dimension lumber from in-grade tests of full-size specimens. West Conshohocken, PA

ASTM International (2014c) ASTM D2395-14: Stand test methods for density and specific gravity (relative density) of wood and woodbased materials. West Conshohocken, PA

Auguie B (2016) gridExtra: Miscellaneous functions for "grid" graphics. $\mathrm{R}$ package version 2.2.1. https://CRAN.Rproject.org/package= gridExtra

Bates D, Maechler M, Bolker B, Walker S (2015) Fitting linear mixedeffects models using lme4. J Stat Softw 67:1-48

Borders BE, Bailey RL (2001) Loblolly pine - pushing the limits of growth. South J Appl For 25:69-74

Butler A, Dahlen J, Daniels RF, Eberhardt TL, Antony F (2016a) Bending strength and stiffness of loblolly pine lumber from intensively managed stands located on the Georgia lower coastal plain. Eur J Wood Prod 47:91-100

Butler A, Dahlen J, Antony F, Kane M, Eberhardt TL, Jin H, Love-Myers K, McTague JP (2016b) Relationships between loblolly pine small clear specimens and dimension lumber tested in static bending. Wood Fiber Sci. In press

Carter P, Chauhan S, Walker J (2006) Sorting logs and lumber for stiffness using director HM200. Wood Fiber Sci 38:49-54

Chang W (2014) extrafont: Tools for using fonts. R package version 0.17. http://CRAN.R-project.org/package=extrafont

Chen ZQ, Karlsson B, Lundqvist SO, Gil MRC, Olsson L, Wu HX (2015) Estimating solid wood properties using Pilodyn and acoustic velocity on standing trees of Norway spruce. Ann For Sci 72:499 508 
Clark A III, Jordan L, Schimleck L, Daniels RF (2008) Effect of initial planting spacing on wood properties of unthinned loblolly pine at age 21. Forest Prod J 58:78-83

Dahlen J, Antony F, Li A, Love-Myers K, Schimleck L, Schilling EB (2015) Time-domain reflectometry for the prediction of loblolly pine and sweetgum moisture content. Bioresources 10:4947-4960

Grabianowski M, Manley B, Walker JCF (2006) Acoustic measurements on standing trees, logs and green lumber. Wood Sci Technol 40:205216

Green DW, Shelley BE, Vokey HP (1989) In-grade testing of structural lumber. In: Proceedings of workshop sponsored by In-grade Testing Committee and Forest Products Society. Proceedings 47363. Madison, WI: Forest Products Society

Hanley JA, McNeil BJ (1982) The meaning and use of the area under a receiver operating characteristic (ROC) curve. Radiology 143:29 36

Hothorn T, Bretz F, Westfall P (2008) Simultaneous inference in general parametric models. Biometrical J 50:346-363

Isik F, Li B (2003) Rapid assessment of wood density of live trees using the Resistograph for selection in tree improvement programs. Can J For Res 33:2426-2435

Kuznetsova A, Brockhoff PB, Christensen RHB (2016) lmerTest: Tests in linear mixed effects models. R package version 2.0-30. https://CRAN.R-project.org/package=lmerTest

Larson PR, Kretschmann DE, Clark III A, Isebrands JG (2001) Formation and properties of juvenile wood in southern pines. US For Serv. Forest Products Laboratory. FPL-TR-129

Lasserre JP, Mason EG, Watt MS, Moore JR (2009) Influence of initial planting spacing and genotype on microfibril angle, wood density, fibre properties and modulus of elasticity in Pinus radiata D. Don corewood. Forest Ecol Manag 258:1924-1931

McAlister RH, Clark A III (1991) Effect of geographic location and seed source on the bending properties of juvenile and mature loblolly pine. Forest Prod J 41:39-42

McKeand S, Mullin T, Bryam T, White T (2003) Deployment of genetically improved loblolly and slash pines in the south. J Forest 101: 32-37

Moore JR, Lyon AJ, Searles GJ, Lehneke SA, Ridley-Ellis DJ (2013) Within- and between-stand variation in selected properties of Sitka spruce sawn timber in the UK: implications for segregation and grade recovery. Ann For Sci 70:403-415. doi:10.1007/s13595013-0275-y

Mora CR, Shimleck LR, Isik F, Mahon JM Jr, Clark A III, Daniels RF (2009) Relationships between acoustic variables and different measures of stiffness in standing Pinus taeda trees. Can J For Res 39: $1421-1429$

Munsell JF, Fox TR (2010) An analysis of the feasibility for increasing woody biomass production from pine plantations in the southern United States. Biomass Bioenerg 34:1631-1642

Murphy G, Cown D (2015) Stand, stem and log segregation based on wood properties: a review. Scan J For Res 30:8, 757-8, 770
Pinheiro J, Bates D, DebRoy S, Sarkar D, R Core Team (2016) nlme: Linear and nonlinear mixed effects models . R package version 3.1127. http://CRAN.R-project.org/package $=$ nlme

R Core Team (2016) R: A language and environment for statistical computing. R Foundation for Statistical Computing, Vienna, Austria. URL http://www.R-project.org/

Ratcliffe B, Hart FJ, Klápště J, Jaquish B, Mansfield SD, El-Kassaby YA (2014) Genetics of wood quality attributes in western larch. Ann For Sci 71:415-424

Robin X, Turck N, Hainard A, Tiberti N, Lisacek F, Sanchez JC, Müller M (2011) pROC: An open-source package for R and S+ to analyze and compare ROC curves. BMC Bioinformatics, 12, p. 77

Ross RJ (2015) Nondestructive evaluation of wood: second edition. USDA Forest Service, Forest Products Laboratory. FPL-GTR-238

Ross RJ, McDonald KA, Green DW, Schad KC (1997) Relationship between $\log$ and lumber modulus of elasticity. Forest Prod J 47: 89-92

RStudio (2016) RStudio: Integrated development environment for R. Boston, MA. https://www.rstudio.com/

Southern Pine Inspection Bureau (SPIB) (2013) Supplement No. 13 to the Southern Pine Inspection Bureau Grading Rules 20012 Edition. 11 February 2013. Southern Pine Inspection Bureau, Pensacola, FL. $11 \mathrm{pp}$

USDA Forest Service (1988) The South's fourth forest; alternative for the future. US For Serv., Forest Resou. Rept. 24. U.S. Gov. Print. Office. Washington, D.C. $512 \mathrm{pp}$

Vance ED, Maguire DA, Zalesney RS Jr (2010) Research strategies for increasing productivity of intensively managed Forest plantations. J Forest 108:183-192

Vikram V, Cherry ML, Briggs D, Cress DW, Evans R, Howe GT (2011) Stiffness of Douglas-fir lumber: effects of wood properties and genetics. Can J For Res 41:1160-1173

Wang X (2013) Acoustic measurements on trees and logs: a review and analysis. Wood Sci Technol 47:965-975

Wang X, Ross RJ, Mattson JA, Erickson JR, Forsman JW, Geske EA, Wehr MA (2002) Nondestructive evaluation techniques for assessing modulus of elasticity and stiffness of small-diameter logs. Forest Prod J 52:79-85

Wang X, Verrill S, Lowell E, Ross RJ, Herian VL (2013) Acoustic sorting models for improved log segregation. Wood Fiber Sc 45:343-352

Wessels CB, Malan FS, Rypstra T (2011) A review of measurement methods used on standing trees for the prediction of some mechanical properties of timber. Eur J Forest Res 130:881-893

Wickham, H (2009) ggplot2: Elegant graphics for data analysis. SpringerVerlag, New York

Wickham H, Francois R (2015) dplyr: A grammar of data manipulation. R package version 0.4.3. https://CRAN.Rproject.org/package=dplyr

Zhi-ru Z, Zhao M-C, Wang Z, Wang BJ, Guan X (2013) Acoustic testing and sorting of Chinese poplar logs for structural LVL products. Bioresources 8:4101-4116 